\title{
Daphne Berdahl, 1964-2007
}

With the untimely death of Daphne Berdahl, anthropology lost one of its leading scholars of central and eastern Europe. The author of the path-breaking book Where the World Ended: Re-Unification and Identity in the German Borderland (1999), Berdahl was a key theorist of the transition from state socialism to capitalism and one of the finest ethnographers the discipline ever produced. She also made important contributions to the anthropology of borderlands, memory, and consumption.

Berdahl was born in 1964 to Margaret and Robert Berdahl, an American historian of Germany and later a prominent university administrator. She grew up in Eugene, Oregon, and attended Oberlin College, where she studied history and German. Following her 1986 graduation, she spent a year each at the University of Tübingen and the University of Illinois, preparing for graduate study in anthropology. In the fall of 1988, she enrolled in the PhD program at the University of Chicago, where she studied with Bernard Cohn, Sharon Stephens, and James Fernandez who became her dissertation advisor.

At the University of Chicago, Berdahl was part of a vibrant group of graduate students who worked on Europe, which, at the time, was still considered marginal to anthropology at large. With her sights set on Germany and a particular interest in borders, she decided to undertake ethnographic research in the Eichsfeld region, an area bisected by the inner-German border. Berdahl arrived in the village of Kella in 1990, witnessing firsthand the immediate aftermath of the Wende and Germany's reunification. After two years of pioneering fieldwork on the postsocialist condition, she returned to Chicago where she completed her doctorate in 1995. She spent the following two years at Harvard University, first as a postdoctoral fellow and then as a lecturer in the Department of Anthropology. In the fall of 1997, she accepted a position at the University of Minnesota, where she received tenure in 2000. At the time of her passing, she was associate professor of anthropology and global studies.

Within the discipline, Berdahl was most strongly identified with the anthropology of postsocialism. As one of its pioneers and leaders, she mounted an important challenge to "transitology," dominated as it was until the late 1990s by political scientists and economists. Against their "linear" and "teleological" narration of the transition in terms of "capitalist 'triumphalism,' "Berdahl championed a view that emphasized "the contradictions, paradoxes, and ambiguities of postsocialism" ("Introduction," in Daphne Berdahl, Matti Bunzl, and Martha Lampland, eds., Altering States: Ethnographies of Transition in Eastern Europe and the Former Soviet Union, 2000, 1). Her work on Ostalgie-she was one of the first scholars to take seriously the nostalgia for state socialism-was a case in point. Scholars in other disciplines tended to regard the phenomenon as a trivial side effect of the largescale transformations. Berdahl, by contrast, recognized it as integral to the transition itself, a position that became the topic of a memorable exchange with Charles Maier at a 1998 conference on historical memory in Vienna. As Berdahl later explicated, Maier's account of the Wende had been "relatively uninterested in the voices and experiences of ordinary Eastern Germans" ("Introduction," 3), the very aspects of everyday life she sought to restore to scholarly view.

Berdahl accomplished this objective to great acclaim in her book Where the World Ended. Based on her dissertation and an additional stint in the field in 1996, this was an exemplary study of the transition. Set in Kella, it was first and foremost an account of the radical and sudden transformations in the village. But in the fashion of anthropology's best ethnographers, Berdahl readily discerned in such local realities the processes of German reunification at large. The village's proximity to the former border was crucial in this respect. Berdahl treated the boundary as both symbolic and real, allowing her to view her interlocutors' frequent border-crossings in both their immediate and historical significance. The result was an on-the-ground account of the emergence of a new East German subjectivity, the Ossi, whose genealogy in the former German Democratic Republic (GDR) was imprinted on her body and behavior and dramatized in her encounters with the west and its Wessis.

Slavic Review 67, no. 1 (Spring 2008) 
In beautifully constructed chapters, Berdahl traced this development in such areas as social structure, religion, and historical memory. Analyzing social transformations in the east, for example, she typically found an analytic inroad in a telling joke: "What is the most difficult [adjustment] for the Ossis since the Wall fell? Having to survive without connections" (Where the World Ended, 115). Explicating the joke through her rich ethnographic material, Berdahl documented how social differentiation in the GDR was marked by an individual's level of Beziehungen, her networks and access to nodes of power. In the new era, Vitamin B (for "Beziehungen") no longer spelled success, one of the many lessons Ossis had to absorb in the wake of the Wende.

Berdahl's descriptions of the lessons in consumption were particularly vivid. During her fieldwork, she frequently accompanied villagers on shopping trips across the former border; and she brilliantly described their "lack of a certain cultural fluency," as in the following passage:

The stereotypical insecure Ossi, for example, walks with her head down and asks the store clerk not where a certain product is but, "Do you have it?"-a practice stemming from an economy of shortages, when the issue was not where a product might be but whether the store even had it. Whereas West Germans could refer to certain products by their brand names-such as Tempo for a tissue, Tesa for adhesive tape, or Uhu for glue-East Germans would describe their function. When people described differences between East and West Germans, they frequently pointed only to consumption practices, "Ossis compare prices," I was often told; "Wessis always know what they want to buy." It was usually during shopping trips in the adjacent western town of Eschwege that people would recriminate themselves for behaving like an Ossi. "Now she probably knows I'm an Ossi," one woman whispered to me about the bakery clerk, "I didn't know what the bread was called" (Where the World Ended, 168).

Katherine Verdery clearly had such passages in mind when she praised Berdahl's book for its "attention to detail" and skill in "giving those details theoretical dimension," adding famously that "it is not often that reading a book for review has led me to rewrite a syllabus I was about to hand out, but that is what happened when I read Where the World Ended" (Verdery, review in American Ethnologist 27, no. 2 [2000]: 545).

Indeed, Where the World Ended is ethnography at its best and an examplar of thick description. Berdahl captured the sights, sounds, and smells of Kella. But what really came to life were its inhabitants. As an ethnographer, Berdahl worked without a tape recorder, drawing her data entirely from participant observation and the copious notes she took at the end of each day. The resulting representations had novelistic qualities, with fully realized settings and characters seamlessly blending into the larger arguments about the transition and German reunification. These qualities have also helped make Where the World Ended a hit in classrooms, where it is equally at home in graduate seminars and introductory undergraduate courses.

Berdahl never rested on the laurels of Where the World Ended. Even before its publication, she conceived an ambitious follow-up project. Building on her previous work on consumption, she wanted to probe its relevance for the creation of new citizenship regimes. The starting point of this investigation was the realization that the key discourses in the transition ultimately turned on a conception of citizens as consumers. The transition, in other words, was less about the achievement of political freedoms (the right to vote in free elections) than the attainment of consumptive privileges (the right to make choices during shopping).

Berdahl began the empirical work on "Citizenship and Mass Consumption in PostWall Germany" in 1998, focusing on Leipzig. With a long tradition of trade fairs, a vast and newly created mall area, and rapid deindustrialization, Leipzig became a paradigmatic space for a study of the "making of citizen-consumers." Berdahl returned to Leipzig for research stays in 2001 and 2003 and continued to work on the project despite her deteriorating health. Her determination, in fact, was extraordinary; and a few months before her death, she was thrilled to win a Guggenheim Fellowship to support the project, parts of which had been published as articles (see especially "The Spirit of Capitalism and the 
Boundaries of Citizenship in Post-Wall Germany," Comparative Studies in Society and History 47, no. 2 [2005]: 235-51).

Along with Where the World Ended and the book series "New Anthropologies of Europe" from Indiana University Press that she coedited, these articles provide the rich intellectual legacy of an exceptional scholar and wonderful human being. A woman of tremendous generosity and kindness, Daphne Berdahl is dearly missed by her many friends and colleagues. In addition to her parents, she is survived by her husband, John Baldwin, and her daughters, Audrey and Eloise.

\author{
Matti BunzL \\ University of Illinois, Urbana-Champaign \\ November 2007
}

\title{
Lindsey Hughes, 1949-2007
}

Lindsey Hughes, professor of Russian history at the University of London's School of Slavonic and East European Studies, died on 26 April 2007. A leading historian of seventeenth- and eighteenth-century Russia for several decades, Hughes was one of the most important specialists on Peter the Great and his time. To many she was a friend as well as a colleague, and she will be missed as much abroad as in Britain.

Born on 4 May 1949 at Swanscombe in Kent, Hughes began to study Russian in secondary school and in 1967 went to Sussex University to continue in Russian. There she studied with Beryl Williams, Sergei Hackel, and Robin Milner-Gulland as well as spending a year in Moscow. She completed her graduate work at Darwin College, Cambridge, working on Moscow Baroque architecture with Nikolay Andreev. Finishing her doctorate in 1976, she began her teaching career at Queen's University Belfast at the height of the troubles in Northern Ireland. In many British universities Russian history was and is taught in the context of Russian studies, and when Hughes moved to Reading University in 1977, she taught literature, language, and history in the Russian department.

Just as Hughes was turning toward history from art history, the British government began to encourage smaller universities to close down Russian departments and centralize instruction in a few large centers. She was transferred in 1987 to the School of Slavonic Studies at London University in 1987, where she remained to the end of her life. By now committed to historical research, she published a brief biography of Prince V. V. Golitsyn in 1984, followed by Sophia, Regent of Russia (1990), the first and only scholarly study of Russia's first female ruler and her policies. Hughes never lost sight of the crucial importance of culture in the transformation of Russia during the late seventeenth century and the reign of Peter the Great. In her most important work, Russia in the Age of Peter the Great (1998), she devoted some 150 pages to cultural matters, as well as many chapters to family, personal networks, and other topics far from the traditional emphasis on institutional and social issues. Her second work on Peter, Peter the Great: a Biography (2002), provided the first biographical treatment of the reforming tsar since that of Reinhard Wittram nearly a half century ago. She managed to complete a study of the Romanov dynasty and had returned to her original interest in the art of the later seventeenth century and Peter's time.

Hughes was a major figure in British Slavic studies, one of the leaders of the Study Group on Eighteenth Century Russia, an important force at the School of Slavonic Studies, and editor of the Slavonic Review. An accomplished guitarist and singer, she had appeared on children's programs on Russian television as a student and in later life participated in local singing groups. She is survived by her husband, Jim Cutshall, who was with her for many years. Her former students as well as her colleagues throughout the world will miss her. 